\title{
Behavioral fever in ectothermic vertebrates
}

\author{
Krzysztof Rakus ${ }^{\text {a, }}$, Maygane Ronsmans ${ }^{\text {b, }}{ }^{\text {, Alain Vanderplasschen }}{ }^{\text {b, * }}$ \\ a Department of Evolutionary Immunology, Institute of Zoology, Jagiellonian University, Gronostajowa 9, 30-387, Krakow, Poland \\ ${ }^{\mathrm{b}}$ Immunology-Vaccinology, Fundamental and Applied Research for Animals \& Health (FARAH), Faculty of Veterinary Medicine, University of Liège, Liège, \\ Belgium
}

\section{A R T I C L E I N F O}

\section{Article history:}

Received 6 April 2016

Received in revised form

29 June 2016

Accepted 30 June 2016

Available online 2 July 2016

\section{Keywords:}

Fever

Behavioral fever

Ectotherms

Innate immunity

Pyrogens

Prostaglandins

\begin{abstract}
A B S T R A C T
Fever is an evolutionary conserved defense mechanism which is present in both endothermic and ectothermic vertebrates. Ectotherms in response to infection can increase their body temperature by moving to warmer places. This process is known as behavioral fever. In this review, we summarize the current knowledge on the mechanisms of induction of fever in mammals. We further discuss the evolutionary conserved mechanisms existing between fever of mammals and behavioral fever of ectothermic vertebrates. Finally, the experimental evidences supporting an adaptive value of behavioral fever expressed by ectothermic vertebrates are summarized.
\end{abstract}

() 2016 Elsevier Ltd. All rights reserved.

\section{Introduction}

Fever is defined as a state of elevated core temperature above its normal range in a defensive response against invading pathogens or lesions (IUPS, 2001). It is a cardinal symptom of many infectious and inflammatory diseases (Evans et al., 2015). This increase of temperature is part of an integrated physiological syndrome accompanied by neuroendocrine and behavioral modifications, which aimed to increase host survival mainly but not exclusively through enhancement of immune defenses (Roth and Blatteis, 2014). Indeed, febrile temperatures can directly impact negatively the growth of invading pathogens (Anderson et al., 2013; Kwiatkowski, 1989; Mackowiak et al., 1982; Martel et al., 2014). Moreover, the raise of body temperature can enhance the efficiency of the immune system by promoting both innate (e.g. by increasing the recruitment of neutrophils with elevated respiratory burst and by enhancing the phagocytic potential of macrophages and dendritic cells) and adaptive immunity (e.g. by increasing the rate of lymphocyte trafficking through lymphoid organs) (Evans et al., 2015; Launey et al., 2011). Beside these salutary aspects, fever is

\footnotetext{
* Corresponding author.

E-mail addresses: krzysztof.rakus@uj.edu.pl (K. Rakus), mronsmans@ulg.ac.be (M. Ronsmans), a.vdplasschen@ulg.ac.be (A. Vanderplasschen).

1 These authors contributed equally to this work.
}

also a metabolically costly defensive response: $(i)$ a rise of core temperature of $1{ }^{\circ} \mathrm{C}$ is correlated with an increase of $10-12.5 \%$ of metabolic rate (Kluger, 1979); (ii) the oxygen consumption is increased notably in the brain and heart which could be detrimental for certain illnesses (Launey et al., 2011); finally, (iii) the risk of seizures is increased in youths (Reid et al., 2009). Nevertheless, both endotherms and ectotherms develop fever, and its conservation and selective evolution over millions of years suggest an adaptive value of this defensive response (Kluger et al., 1998).

\section{Fever in mammals}

\subsection{Exogenous and endogenous pyrogens}

Fever is classically induced through a humoral pathway (Roth and Blatteis, 2014). Its signaling starts with the recognition of pathogen-associated molecular patterns (PAMPs) and/or damageassociated molecular patterns (DAMPs) by immune cells (Atkins and Bodel, 1979; Blatteis, 2006). These stimuli, named exogenous pyrogens, are detected through germline-encoded pattern recognition receptors (PRR), a.e. the Toll-like receptors (TLR), which recognize conserved structures of microorganisms or signatures of tissue lesion (O'Neill et al., 2013). These PRR are expressed by innate immune cells including macrophages, dendritic cells and neutrophils and upon activation, trigger proinflammatory and 
antimicrobial reactions (Mogensen, 2009). Notably, their activation induces the release of pyrogenic cytokines called endogenous pyrogens such as interleukin (IL) $1 \beta$, IL6, tumor necrosis factor $\alpha$ (TNF $\alpha$ ), and interferons (IFN) (Dinarello, 1999; Netea et al., 2000). Both IL1 $\beta$ and TNF $\alpha$ can induce the expression of each other (Dinarello et al., 1986; Ikejima et al., 1990) and are potent inducers of IL6 (Zetterstrom et al., 1998), which on contrary tends to be an inhibitor of IL1 $\beta$ and TNF $\alpha$ production (Netea et al., 2000; Schindler et al., 1990). IL6 seems to be the major mediator for sustaining fever; indeed, IL6-knockout mice or IL6-neutralizing antibodiesinjected mice were not able to develop LPS-induced fever, even if TNF $\alpha$ and IL1 $\beta$ upregulation was unaltered (Chai et al., 1996; Hamzic et al., 2013; Kozak et al., 1998).

\subsection{The humoral pathway}

Endogenous pyrogens produced locally migrate through the bloodstream to the brain where they penetrate the preopticanterior hypothalamic area (POA) either by active transendothelial transport (Banks, 2005) or by diffusion through the organum vasculosum laminae terminalis (OVLT) (McKinley et al., 2003; Roth et al., 2004). The OVLT belongs to the sensory circumventricular organs (CVOs), which all lack a tight blood-brain barrier but rather present a fenestrated endothelium. Endogenous pyrogens activate nuclear factor-kappa B (NF- $\mathrm{B}$ ) (Laflamme and Rivest, 1999) and signal transducer and activator of transcription-3 (STAT3) (Rummel et al., 2005), transcription factors in brain endothelial cells of a particular locus of the POA called the median preoptic nucleus (MnPO). These transcription factors target several genes among which those encoding the cyclooxygenase 2 (COX2) and the microsomal PGE synthase 1 (mPGES1), both involved in the synthesis of prostaglandin (PG) $\mathrm{E}_{2}\left(\mathrm{PGE}_{2}\right)$ (Nadjar et al., 2005; Rummel et al., 2005, 2006). This results in an increase of $\mathrm{PGE}_{2}$ in the MnPO. As an alternative or parallel pathway, the CVOs but also some endothelial and perivascular brain cells bearing TLRs (Crack and Bray, 2007; Rivest, 2003), can react to PAMPs or circulating cytokines and directly secrete $\mathrm{PGE}_{2}$, cytokines or other mediators in the brain (Fig. 1a).

\subsection{The key role of $P G E_{2}$}

$\mathrm{PGE}_{2}$ is considered as a major pyrogenic mediator of fever (Engstrom et al., 2012; Matsumura et al., 1998; Yamagata et al., 2001). The role of $\mathrm{PGE}_{2}$ in induction of fever in mammals was already reported in 1971 by Milton and Wendlandt (1971) who demonstrated that microinjection of $\mathrm{PGE}_{2}$ into the third ventricle of conscious cats and rabbits cause a rise of body temperature. The subsequent studies using inhibitors of $\mathrm{PGE}_{2}$ synthesis clearly confirmed that $\mathrm{PGE}_{2}$ plays essential role in fever expressed by mammals (reviewed by Ivanov and Romanovsky, 2004; Blatteis et al., 2005).

$\mathrm{PGE}_{2}$ biosynthesis involves three successive enzymatic reactions (Pecchi et al., 2009): firstly, arachidonic acid (AA) is released by the action of phospholipase A2 (PLA2) on the cell membrane phospholipids; secondly, $\mathrm{AA}$ is metabolized in $\mathrm{PGG}_{2}$ then converted to $\mathrm{PGH}_{2}$ by the action of COX; thirdly, $\mathrm{PGH}_{2}$ is finally metabolized in $\mathrm{PGE}_{2}$ by the mPGES1. Two principal isoforms of COX enzymes are described, COX1 and COX2 (Pecchi et al., 2009). While the COX1 is constitutively expressed in many tissues, COX2 is mainly an inflammatory-inducible enzyme as mPGES1. Both COX2 (Steiner et al., 2005) and mPGES1 (Engblom et al., 2003) were shown to be indispensable for LPS-induced fever. In addition to the $\mathrm{PGE}_{2}$ locally produced in the brain, $\mathrm{PGE}_{2}$ can also be secreted at the periphery predominantly by hepatic and pulmonary macrophages ( $\mathrm{Li}$ et al., 2006; Simm et al., 2016; Steiner et al., 2006). This peripheral
$\mathrm{PGE}_{2}$ binds to albumin which protects it from enzymatic degradation during its journey to the brain via the bloodstream (Ivanov and Romanovsky, 2004). Independently of its peripheral or cerebral origin, $\mathrm{PGE}_{2}$ bind to a $\mathrm{PGE}_{2}$ receptors on a specific group of neurons in the median preoptic nucleus (MnPO). Four subtypes of $\mathrm{PGE}_{2}$ receptors have been described, namely EP1-EP4 (Oka, 2004), among which EP3 was shown to be critical in the induction of fever (Lazarus et al., 2007; Saper et al., 2012; Ushikubi et al., 1998). These EP3 receptor-bearing neurons are GABAergic neurons (Nakamura et al., 2002), which through neuronal projections inhibit the activity of neurons in dorsomedial nucleus of the hypothalamus (DMH) and rostral medullary raphe (rMR) (Nakamura, 2011). The binding of $\mathrm{PGE}_{2}$ to the EP3 receptor-bearing neurons reduces their activity and so disinhibits the downstream neurons in the DMH and rMR. The disinhibition of neurons in the DMH induces excitatory outputs on sympathetic premotor neurons in the rMR, which in turn activate the sympathetic preganglionic neurons (Nakamura, 2011). This triggers the release of norepinephrine (NE) which elicits intrinsic thermogenesis in brown adipose tissue (non-shivering thermogenesis) and heat conservation by peripheral vasoconstriction. Moreover, the disinhibition of rMR neurons excites the somatomotor neurons which release acetylcholine (ACh) and activate skeletal muscles for shivering. The increased thermogenesis by shivering and non-shivering dependent processes and the reduction of heat loss by peripheral vasoconstriction lead to the elevation of core temperature (Nakamura, 2011; Saper et al., 2012) (Fig. 1a).

\subsection{The neural pathway}

Alternatively to the classical humoral activation pathway described above, a neural pathway was also suggested for the induction of fever. It relies on the stimulation of peripheral sensory nerves, i.e. vagal (Blatteis et al., 2000; Romanovsky, 2000) and trigeminal (Navarro et al., 2006) afferences by $\mathrm{PGE}_{2}$. The presumed pathway consists of a first synapse in the nucleus of the solitary tract (NTS), followed by travelling of the signal via ventral noradrenergic bundle to the POA where it induces the release of $\mathrm{NE}$, hence stimulating synthesis of $\mathrm{PGE}_{2}$. This neural stimulation of fever is presumed to be responsible for short onset of fever, as compared to fever resulting from the humoral pathway (Roth and Blatteis, 2014).

\subsection{Thermoregulatory behaviors}

Beside the increase of core temperature, fever expression in mammals also involves several behavioral responses such as warmth seeking (Almeida et al., 2006). Neither the neural pathways controlling these behaviors nor the role of $\mathrm{PGE}_{2}$ in this context have been unravelled (Saper et al., 2012). Craig (2002) postulated that neural pathways for discriminatory thermal sensitivity could follow the thalamo-cortical pathways (Craig, 2002). Moreover, experiments in rats with important electrolytic lesions performed in the POA demonstrate that destruction of this brain region does not impact their ability to express thermoregulatory behaviors but impair their capacity for autonomic thermoregulation (Almeida et al., 2006). In conclusion, the neural pathways controlling these behaviors are different from those controlling autonomic thermogenesis (Nakamura, 2011; Saper et al., 2012). Further investigations are required to unravel the induction pathways of behavioral thermoregulation in endotherms.

\section{Regional endothermy in ectothermic vertebrates}

Ectotherms, in most of the cases, have a body temperature very close to the temperature of the environment in which they reside. 


\section{a. Mammals}

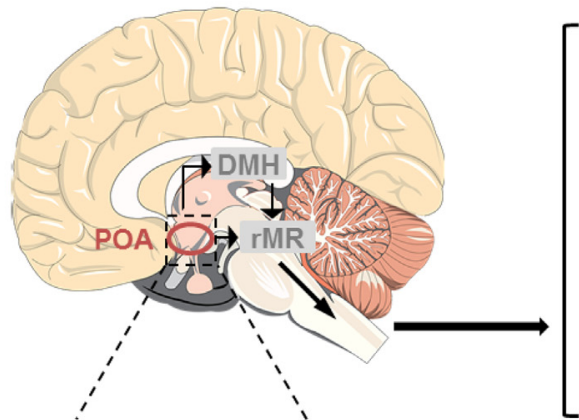

Median preoptic nucleus

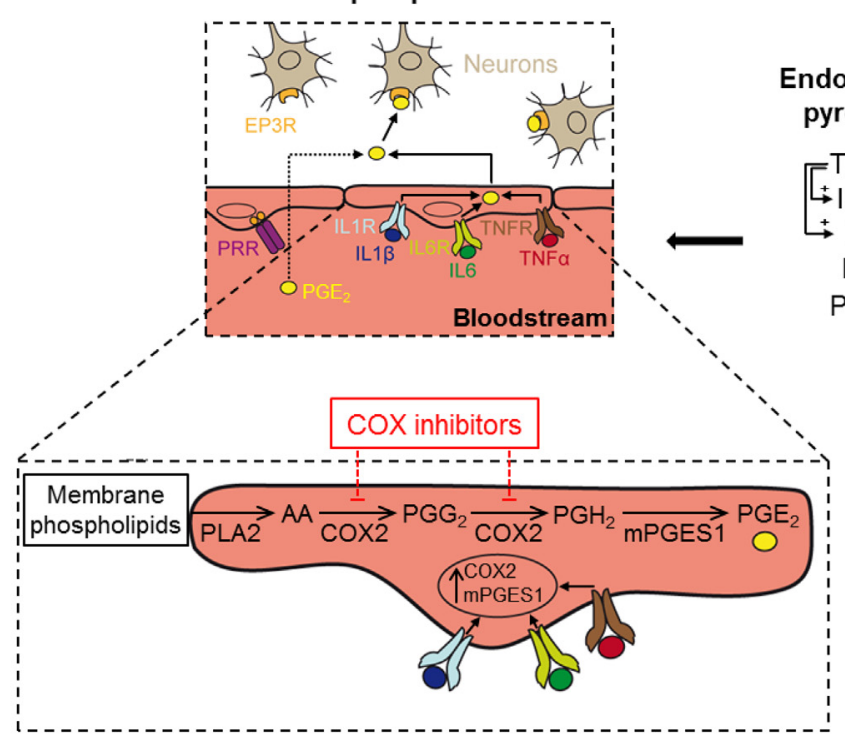

\section{b. Ectothermic vertebrates}
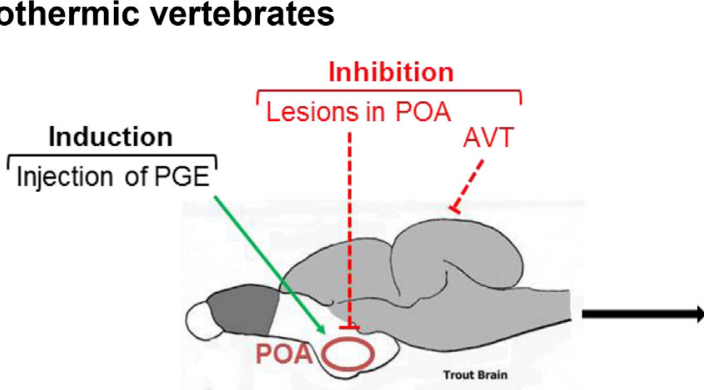

Inhibition

\begin{tabular}{|c|c|}
\hline $\begin{array}{c}\text { Sodium salicylate } \\
\text { Indomethacin } \\
\text { Acetaminophen }\end{array}$ & \\
\hline
\end{tabular}

Hypothalamus

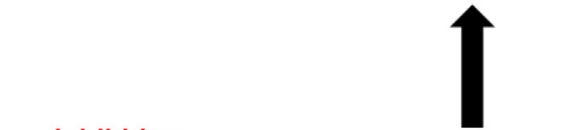

\section{Norepinephrine}

Brown adipose tissue thermogenesis

Peripheral vasoconstriction

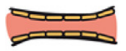

\section{Acetylcholine}

Shivering

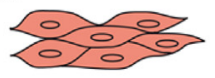

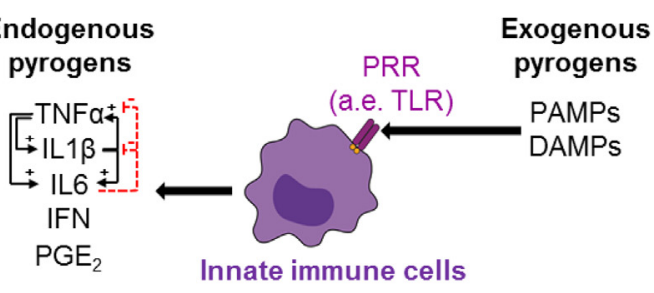

Behavioral

fever

Final thermal preferendum

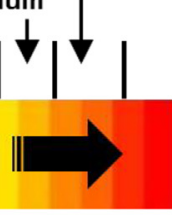

Temperature gradient

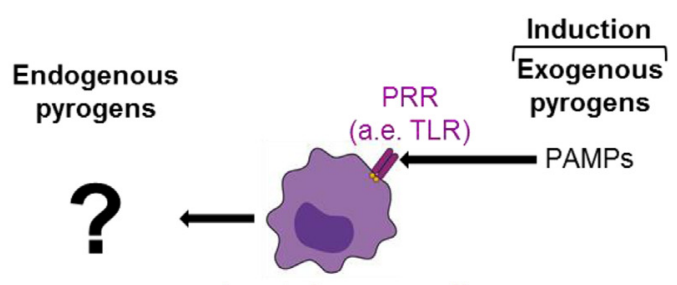

Innate immune cells

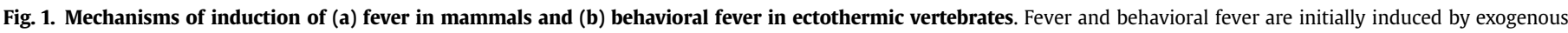

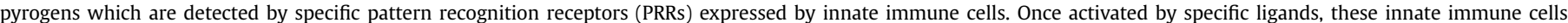

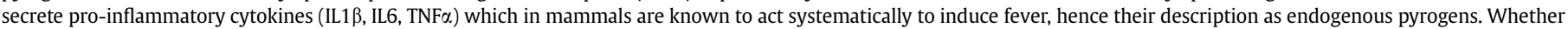

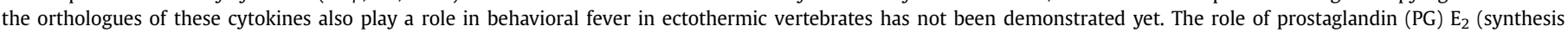

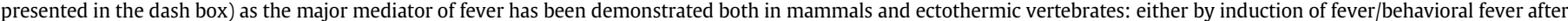

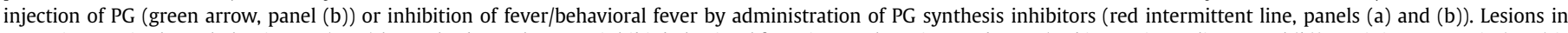

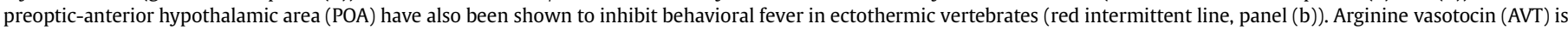

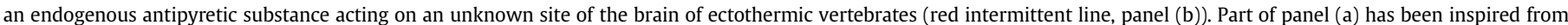

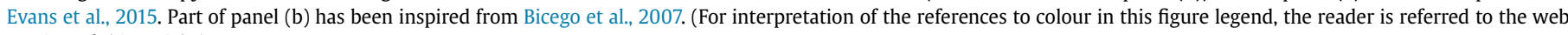
version of this article.) 
Therefore, they mostly control their body temperature by thermoregulatory movement behavior. In a temperature gradient, ectotherms select a species-specific range of preferred temperature which is defined as final thermal preferendum. Besides behavior, some ectothermic vertebrates including pythons (Hutchison et al., 1966), tegu lizard (Tattersall et al., 2016) and a small number of fish species (less than $0.1 \%$ of described fish), such as tunas (family Scombridae), lamnid sharks (family Lamnidae), and billfishes (families Istiophoridae and Xiphiidae) (Bernal et al., 2001, 2005; Block and Finnerty, 1994; Block et al., 1993; Dickson and Graham, 2004), are able to maintain a higher temperature of specific tissues and organs by endogenous thermogenesis. These animals are called facultative or regional endotherms. Thermogenesis in both pythons and tegu lizards is observed during reproductive season (Hutchison et al., 1966; Tattersall, 2016). In brooding pythons, it is based on shivering and it leads to the increase of the incubation temperature of the eggs (Harlow and Grigg, 1984). Fish belonging to regional endotherms generate heat in few muscles during locomotory activity (Carey and Teal, 1966). These fish have countercurrent vascular heat exchanger systems called retia mirabilia ("wonderful nets"). It is composed of small arterioles and venules that are closely opposed to allow heat transfer from out-flowing warm venous blood arriving from the heat producing organ to inflowing cold arterial blood arriving from the gills. This allows a very efficient retention of internally generated heat and its distribution to specific organs (Carey and Teal, 1966; Block, 1991, 1994). Elevated temperature in these specific organs has advantages related to the increasing swimming speed and distains. It may also increase the rate of digestion and absorption of food, as well as may improve vision and brain functions (Block and Carey, 1985; Carey and Teal, 1966; Goldman, 1997; Stevens and Fry, 1971). Very recently, a whole-body form of endothermy has been described in a large, mesopelagic fish, the oprah (Lampris guttatus) (Wegner et al., 2015). Oprah produces heat by the dark red aerobic pectoral musculature, which is used during swimming. Unlike other fish, oprah has retia mirabilia inside thick, fat-insulated gill arches and distributed heat through the whole body (including heart) by the circulatory system (Wegner et al., 2015).

\section{Behavioral fever in ectothermic vertebrates}

In response to infection or injection of exogenous pyrogens, ectotherms can increase their body temperature above their usual final thermal preferendum. This process occurs through behavioral regulation, which leads the animals to migrate to warmer environment. This phenomenon is known as behavioral fever and is defined as an acute increase of the final thermal preferendum driven by pathogen infection (Evans et al., 2015; Reynolds and Casterlin, 1982).

The first description of behavioral fever in ectotherms was published 40 years ago by Vaughn et al. (1974) who demonstrated that desert iguana (Dipsosaurus dorsalis) injected with killed Gramnegative bacterium Aeromonas hydrophila tend to migrate to warmer environment, which resulted in increase of body temperature of approximately $2{ }^{\circ} \mathrm{C}$ (Vaughn et al., 1974). Up to date, behavioral fever has been described in all groups of ectothermic vertebrates including reptiles (Bernheim and Kluger, 1976a,b; Burns et al., 1996; do Amaral et al., 2002; Hallman et al., 1990; Kluger et al., 1975; Merchant et al., 2007, 2008; Monagas and Gatten, 1983; Muchlinski et al., 1995; Ortega et al., 1991; Ramos et al., 1993; Vaughn et al., 1974), amphibians (Casterlin and Reynolds, 1977; Kluger, 1977; Murphy et al., 2011; Myhre et al., 1977; Richards-Zawacki, 2010; Sherman et al., 1991), fish (Boltaña et al., 2013; Cabanac and Laberge, 1998; Covert and Reynolds, 1977; Grans et al., 2012; Reynolds, 1977; Reynolds et al., 1976, 1978) but also in invertebrates (Campbell et al., 2010; Elliot et al., 2002) and newborn mammals, which in response to bacterial pyrogens are unable to develop fever physiologically but do so behaviorally (Satinoff et al., 1976). However, there have been some contrasting data showing that injection of pyrogens, killed bacteria or parasites in some species of lizards (Don et al., 1994; Hallman et al., 1990; Laburn et al., 1981; Muchlinski et al., 1995; Ortega et al., 1991; Schall, 1990), turtles (Zurovsky et al., 1987b), snakes (Burns et al., 1996; Zurovsky et al., 1987a) and fish (Marx et al., 1984), did not result in febrile response and increase of final thermal preferendum. These negative results have been subsequently discussed. Several factors might have affected the results of these experiments: ( $i$ ) the use of inappropriate dose of pyrogenic substances or bacteria, (ii) the use of various temperature gradient systems, and (iii) seasonal changes (Bicego et al., 2007; Cabanac, 1990). Moreover, it has been suggested that febrile response did actually occur in the experiments of Laburn et al. (1981) and Zurovsky et al. (1987a,b), but were masked by identical responses due to stress consequent to handling for the saline injections (Cabanac, 1990). Several other reports of behavioral fever in the same orders of reptiles and fish suggest that behavioral fever in ectothermic vertebrates seems to be a common response of these organisms against different exogenous pyrogens.

Most of the studies on behavioral fever in ectothermic vertebrates have been performed under laboratory-based conditions, using different animal models and systems to monitor the changes in thermal preferendum after infection or injection by pyrogenic substances. However, Richards-Zawacki (2010) demonstrated that in natural conditions the wild Panamanian golden frogs (Atelopus zeteki) are able to increase their body temperature by behavioral movement in response to infection with pathogenic chytrid fungus Batrachochytrium dendrobatidis. Author reported that mean frog body temperatures were higher during the epidemic periods as compared to pre-epidemic periods and this change was not related to differences in environmental temperature during sampling periods (Richards-Zawacki, 2010).

\subsection{Exogenous pyrogens in ectothermic vertebrates}

Various exogenous pyrogens have been demonstrated to induce behavioral fever in ectothermic vertebrates (Fig. 1b) including LPS (Cabanac and Laberge, 1998; do Amaral et al., 2002; Grans et al., 2012; Merchant et al., 2007, 2008; Reynolds et al., 1978; Sherman et al., 1991), various species of Gram-positive and Gram-negative bacteria, administrated as killed or live forms (Bernheim and Kluger, 1976a,b; Burns et al., 1996; Casterlin and Reynolds, 1977; Covert and Reynolds, 1977; Hallman et al., 1990; Kluger, 1977; Kluger et al., 1975; Monagas and Gatten, 1983; Muchlinski et al., 1995; Myhre et al., 1977; Ortega et al., 1991; Ramos et al., 1993; Reynolds, 1977; Reynolds et al., 1976, 1978; Vaughn et al., 1974), fungi (Murphy et al., 2011; Richards-Zawacki, 2010), ectoparasite (Gyrodactylus turnbulli) (Mohammed et al., 2016), synthetic dsRNA (poly I:C) (Boltaña et al., 2013) or viruses (Boltaña et al., 2013). Because of the relatively low sensitivity of fish and toads to LPS, the dose used to induce behavioral fever in these animals (toad: $200 \mu \mathrm{g} / \mathrm{kg}$, injected into the lymph sac (Bicego-Nahas et al., 2000); fish: $1000 \mu \mathrm{g} / \mathrm{kg}$, injected intraperitoneally (Grans et al., 2012)) is 20-200 times higher than those effective to induce fever in rats (5 $\mu \mathrm{g} / \mathrm{kg}$, injected intravenously (Soares et al., 2009); $50 \mu \mathrm{g} / \mathrm{kg}$, injected intraperitoneally (Tavares et al., 2006)) and guinea pigs (10 $\mu \mathrm{g} / \mathrm{kg}$, injected intra-arterially (Roth and de Souza, 2001)).

Behavioral fever in ectothermic vertebrates is induced by pyrogens in a dose-dependent manner (do Amaral et al., 2002; Ramos et al., 1993). However, different pyrogens have different effects on the febrile response when administered to the same animal species. 
For example, in alligators (Alligator mississippiensis), intraperitoneal injection of heat-killed $A$. hydrophila, a Gram-negative bacterium known to infect crocodilians, resulted in an increased body temperature, while injection of the same dose of Staphylococcus aureus (Gram-positive) did not elicit a febrile response (Merchant et al., 2007). The injections of heat-killed pathogenic Mycobacterium (M. xenopi and M. ranae) into frog (Rana esculenta) caused behavioral fever while non-pathogenic bacteria (M. aquae II) caused no change in temperature preferendum (Myhre et al., 1977).

Apart from exogenous pyrogens, increase of the body temperature has been also induced by handling in lizard (Callopistes maculatus) (Cabanac and Gosselin, 1993), and turtle (Clemmys insculpta) (Cabanac and Bernieri, 2000), but not in toads (Cabanac and Cabanac, 2004) and goldfish (Carassius auratus) (Cabanac and Laberge, 1998). However, very recent study demonstrated stressinduced hyperthermia in zebrafish (Danio rerio) (Rey et al., 2015). The raise of body temperature originating from stress is called emotional fever and is well described in mammals (Briese and Cabanac, 1991; Briese and De Quijada, 1970).

\subsection{Evolutionary conserved mechanisms existing between fever of mammals and behavioral fever of ectothermic vertebrates}

As mentioned before, the preoptic area (POA) of the brain of mammals plays an important role in thermoregulation and in the induction of fever. It is also known to be a thermoregulatory center of non-mammalian vertebrates, and temperature-sensitive neurons have been reported in POA of fish and reptiles (Cabanac et al., 1967; Nelson and Prosser, 1979; Prosser and Nelson, 1981). Bicego and Branco (2002) demonstrated a role of the POA in the behavioral fever induced by LPS in toads Bufo paracnemis. Electrolytic lesions in the POA completely abolished LPS-induced behavioral fever, whereas lesions outside the POA did not affect the febrile response (Bicego and Branco, 2002).

A few studies performed on the regulation of behavioral fever in ectothermic vertebrates have suggested an evolutionary conserved role of PGs between behavioral fever of ectothermic vertebrates and fever of mammals. Two experimental strategies have been applied to test the role of PG in the expression of behavioral fever in ectothermic vertebrates: $(i)$ induction of behavioral fever by injection of PG or (ii) inhibition of behavioral fever expression by administration of PG synthesis inhibitors. Microinjection of $\mathrm{PGE}_{1}$ into the third ventricle of the brain of the salamander Necturus maculosus (Hutchison and Erskine, 1981) or into the diencephalon of the frog Rana esculenta (Myhre et al., 1977) resulted in an increase of the final thermal preferendum. There is, however, one contrasting study showing no behavioral fever in fish Lepomis gibbosus after PGE $_{1}$ injection (Marx et al., 1984). The inhibition of PG synthesis by the use of COX inhibitors, sodium salicylate (Bernheim and Kluger, 1976a,b) and indomethacin (Bicego et al., 2002), attenuated the behavioral fever induced by bacteria $A$. hydrophila in lizard Dipsosaurus dorsalis and by LPS in toads Bufo paracnemis, respectively. The antipyretic drug acetaminophen, when dissolved in the water, counteracts the febrile response of fish Lepomis macrochirus to bacterial pyrogen, possibly by inhibiting production and/or release of PGs (Reynolds, 1977).

In fish, increase of $\mathrm{PGE}_{2}$ level after in vitro stimulation of primary macrophage cultures with LPS as well as up-regulation of COX2 gene after in vivo infection with bacteria Aeromonas salmonicida, was demonstrated (Zou et al., 1999). Moreover, increased level of plasma $\mathrm{PGE}_{2}$ was correlated with the induction of behavioral fever in dsRNA-challenged zebrafish (Boltaña et al., 2013). These data, together with studies using COX inhibitors strongly indicate that synthesis of PG seems to be necessary for the expression of behavioral fever in ectothermic vertebrates (Fig. 1b).
Much less is known about the endogenous pyrogens in ectothermic vertebrates. Myhre et al. (1977) demonstrated an increase of final thermal preferendum in frog Rana esculenta, injected with blood plasma from frogs pre-injected with pathogenic bacteria M. ranae (Myhre et al., 1977). Also, lizards Dipsosaurus dorsalis developed behavioral fever after injection of supernatant collected from ex vivo incubated leukocytes isolated from peritoneal cavity of lizards pre-injected with dead A. hydrophila or 3\% thioglycollatesaline solution, as well as from rabbits in which fever was previously induced (Bernheim and Kluger, 1977). Injection of denatured supernatants did not affect body temperature (Bernheim and Kluger, 1977). While these results suggest that peripheral PGs or cytokine mediators could act as endogenous pyrogens in ectothermic vertebrates like in endotherms, this has never been demonstrated.

Similarly, little is known about endogenous antipyretic substances in ectotherms. Studies in toads Bufo paracnemis revealed that arginine vasotocin (AVT), the non-mammalian analogue of the mammalian antipyretic molecule arginine vasopressin (AVP), has antipyretic functions and abolished LPS-induced behavioral fever by acting in an unknown site of the brain (Bicego-Nahas et al., 2000). However, more studies are needed to determine the nature of endogenous antipyretics and mechanisms of their actions in ectothermic vertebrates.

\section{Adaptive value of behavioral fever in ectothermic vertebrates}

A great advantage of using ectothermic vertebrates as animal models to study fever was demonstrated in the research aiming to resolve the question on the adaptive value of fever. Indeed, it revealed that ectothermic vertebrates are better able to fight infection by increasing their body temperature as a consequence of behavioral fever expression. Prevention of behavioral fever development during bacterial infection with $A$. hydrophila in lizards Dipsosaurus dorsalis, by physical (Kluger et al., 1975) or pharmacological means (injection of sodium salicylate) (Bernheim and Kluger, 1976a), as well as in fish Carassius auratus by physical means (Covert and Reynolds, 1977), was harmful to infected animals and resulted in higher mortality as compared to individuals which were allowed to express behavioral fever. Recently, Boltaña et al. (2013) demonstrated that zebrafish (Danio rerio) infected with spring viremia of carp virus (SVCV) and allowed to express behavioral fever, rapidly combat viral infection, do not develop clinical symptoms of infection and clear replicating virus from the body, in contrast to zebrafish held under constant conditions (Boltaña et al., 2013).

Studies using wild golden frog populations (Atelopus zeteki) revealed that unrelated to the changes of environmental temperatures, both infected (with $B$. dendrobatidis) and uninfected frogs had higher average body temperatures during epidemic periods as compared to pre-epidemic, and uninfected frogs exhibited even higher average temperatures than infected frogs (RichardsZawacki, 2010). One of the hypothesis to explain this finding was the possible latency to return to a normal body temperature after resolution of the infection that was never monitored in laboratorybased studies. Author suggested that maintaining an elevated body temperature for a longer time might allow complete clearing of the fungal infection as well as protecting frogs from resurgence of infection (Richards-Zawacki, 2010). However, this hypothesis needs to be tested in laboratory-based conditions where individual infection status of each studied animals can be monitored during the onset of behavioral fever.

Elevation of temperature above the final thermal preferendum reduces the growth rate and survival of the pathogens but also 
affects the activity of the host immune system. There are only two studies demonstrating the direct effect of the changes in thermal preference driven by behavioral fever on immune parameters in fish. Grans et al. (2012) demonstrated significantly higher IL1 $\beta$ expression in head kidney of rainbow trout (Oncorhynchus mykiss) injected with LPS and subjected to simulated behavioral fever by increasing water temperature of $2.5^{\circ} \mathrm{C}$ (up to $16.0^{\circ} \mathrm{C}$ ) after injection, as compared to fish that were injected with LPS and kept in constant water temperature of $13.5{ }^{\circ} \mathrm{C}$ (Grans et al., 2012). The study of Boltaña et al. (2013) suggested that behavioral fever induced by injection of zebrafish with synthetic dsRNA (poly I:C) and demonstrated by shift in thermal preference from $29.4{ }^{\circ} \mathrm{C}$ to $33.1{ }^{\circ} \mathrm{C}$, promotes the emergence of a highly specific anti-viral immune response by induction of the transcription of specific genes in brains of zebrafish (Boltaña et al., 2013). This is in accordance with previous observations that higher temperature has a positive effect on viral clearance in fish (Avunje et al., 2012; Novoa et al., 2010). Moreover, behavioral fever significantly affected transcription of neuroregulatory receptors and in particular components of the inflammatory reflex, $\alpha 7$ nicotinic acetylcholine receptor $(\alpha 7 \mathrm{nAChR})$ and acetylcholinesterase (AChE) in the brain, suggesting that behavioral fever plays a role in inhibition of antiinflammatory reflex and provides conditions for increased antiviral responses (Boltaña et al., 2013).

\section{Conclusions}

Behavioral fever in ectotherms and fever in endotherms are evolutionary related responses to infections. Despite relying on different physiological mechanisms, key observations such as the role of the hypothalamus and PG synthesis in both processes demonstrated their common phylogenetic origin. Together with the observation that behavioral fever also exists in invertebrates, the data summarized in this manuscript demonstrate that the expression of a febrile response to an infection is a very ancestral acquisition in evolution. Its conservation and adaptation for millions of years in both ectotherms and endotherms support the selective advantages it confers to the infected hosts. While the homology between the regulation pathways of behavioral fever and fever has been demonstrated at the level of the central nervous system, this homology has not been extended to endogenous pyrogens yet. Further studies are required to determine whether the orthologues of the cytokines identified as endogenous pyrogens in endotherms also play a role in behavioral fever of ectotherms. The development of zebrafish as a model organism for immunological and physiological studies in fish, together with the emergence of new mutagenesis techniques (e.g. CRISPR/Cas9) provides new possibilities to study the mechanism of behavioral fever in ectothermic vertebrates.

\section{Conflict of interest}

The authors declare no conflict of interests.

\section{Acknowledgements}

This work was supported by the University of Liège, the Belgian Science Policy (Belspo) (BELVIR IAP7/45), the Fonds National Belge de la Recherche Scientifique (FNRS) (CDR J.0230.16), and Jagiellonian University in Krakow (K/ZDS/005405).

\section{References}

Almeida, M.C., Steiner, A.A., Branco, L.G., Romanovsky, A.A., 2006. Cold-seeking behavior as a thermoregulatory strategy in systemic inflammation. Eur. J.
Neurosci. 23, 3359-3367.

Anderson, R.D., Blanford, S., Jenkins, N.E., Thomas, M.B., 2013. Discriminating fever behavior in house flies. PLoS One 8, e62269.

Atkins, E., Bodel, P., 1979. Clinical fever: its history, manifestations and pathogenesis. Fed. Proc. 38, 57-63.

Avunje, S., Kim, W.S., Oh, M.J., Choi, I., Jung, S.J., 2012. Temperature-dependent viral replication and antiviral apoptotic response in viral haemorrhagic septicaemia virus (VHSV)-infected olive flounder (Paralichthys olivaceus). Fish Shellfish Immunol. 32, 1162-1170.

Banks, W.A., 2005. Blood-brain barrier transport of cytokines: a mechanism for neuropathology. Curr. Pharm. Des. 11, 973-984.

Bernal, D., Dickson, K.A., Shadwick, R.E., Graham, J.B., 2001. Review: analysis of the evolutionary convergence for high performance swimming in lamnid sharks and tunas. Comp. Biochem. Physiol. A Mol. Integr. Physiol. 129, 695-726.

Bernal, D., Donley, J.M., Shadwick, R.E., Syme, D.A., 2005. Mammal-like muscles power swimming in a cold-water shark. Nature 437, 1349-1352.

Bernheim, H.A., Kluger, M.J., 1976a. Fever and antipyresis in the lizard Dipsosaurus dorsalis. Am. J. Physiol. 231, 198-203.

Bernheim, H.A., Kluger, M.J., 1976b. Fever: effect of drug-induced antipyresis on survival. Science 193, 237-239.

Bernheim, H.A., Kluger, M.J., 1977. Endogenous pyrogen-like substance produced by reptiles. J. Physiol. 267, 659-666.

Bicego-Nahas, K.C., Steiner, A.A., Carnio, E.C., Antunes-Rodrigues, J., Branco, L.G., 2000. Antipyretic effect of arginine vasotocin in toads. Am. J. Physiol. Regul. Integr. Comp. Physiol. 278, R1408-R1414.

Bicego, K.C., Barros, R.C.H., Branco, L.G.S., 2007. Physiology of temperature regulation: comparative aspects. Comp. Biochem. Physiol. A Mol. Integr. Physiol. 147, 616-639.

Bicego, K.C., Branco, L.G., 2002. Discrete electrolytic lesion of the preoptic area prevents LPS-induced behavioral fever in toads. J. Exp. Biol. 205, 3513-3518.

Bicego, K.C., Steiner, A.A., Antunes-Rodrigues, J., Branco, L.G., 2002. Indomethacin impairs LPS-induced behavioral fever in toads. J. Appl. Physiol. 93, 512-516.

Blatteis, C.M., 2006. Endotoxic fever: new concepts of its regulation suggest new approaches to its management. Pharmacol. Ther. 111, 194-223.

Blatteis, C.M., Li, S., Li, Z., Feleder, C., Perlik, V., 2005. Cytokines, PGE2 and endotoxic fever: a re-assessment. Prostagl. Other Lipid Mediat 76, 1-18.

Blatteis, C.M., Sehic, E., Li, S., 2000. Pyrogen sensing and signaling: old views and new concepts. Clin. Infect. Dis. 31, 168-177.

Block, B.A., 1991. Endothermy in fish: thermogenesis, ecology and evolution. In: Hochachka, P.W., Mommsen, T.P. (Eds.), Biochemistry and Molecular Biology of Fishes. Elsevier, New York, pp. 269-311.

Block, B.A., 1994. Thermogenesis in muscle. Annu. Rev. Physiol. 56, 535-577.

Block, B.A., Carey, F.G., 1985. Warm brain and eye temperatures in sharks. J. Comp. Physiol. B 156, 229-236.

Block, B.A., Finnerty, J.R., 1994. Endothermy in fishes: a phylogenetic analysis of constraints, predispositions, and selection pressures. Environ. Biol. Fishes 40, 283-302.

Block, B.A., Finnerty, J.R., Stewart, A.F., Kidd, J., 1993. Evolution of endothermy in fish: mapping physiological traits on a molecular phylogeny. Science 260, 210-214.

Boltaña, S., Rey, S., Roher, N., Vargas, R., Huerta, M., Huntingford, F.A., Goetz, F.W., Moore, J., Garcia-Valtanen, P., Estepa, A., MacKenzie, S., 2013. Behavioural fever is a synergic signal amplifying the innate immune response. Proc. R. Soc. B Biol. Sci. 280.

Briese, E., Cabanac, M., 1991. Stress hyperthermia: physiological arguments that it is a fever. Physiol. Behav. 49, 1153-1157.

Briese, E., De Quijada, M.G., 1970. Colonic temperature of rats during handling. Acta Physiol. Lat. Am. 20, 97-102.

Burns, G., Ramos, A., Muchlinski, A., 1996. Fever response in North American snakes. J. Herpetol. 30, 133-139.

Cabanac, A.J., Cabanac, M., 2004. No emotional fever in toads. J. Therm. Biol. 29, 669-673.

Cabanac, M., 1990. Phylogeny of fever. In: Bligh, J., Voigt, K., Braun, H.A., Brück, K., Heldmaier, G. (Eds.), Thermoreception and Temperature Regulation. Springer Berlin Heidelberg, Berlin, Heidelberg, pp. 284-296.

Cabanac, M., Bernieri, C., 2000. Behavioral rise in body temperature and tachycardia by handling of a turtle (Clemmys insculpta). Behav. Process. 49, 61-68.

Cabanac, M., Gosselin, F., 1993. Emotional fever in the lizard Callopistes maculatus (Teiidæ). Anim. Behav. 46, 200-202.

Cabanac, M., Hammel, T., Hardy, J.D., 1967. Tiliqua scincoides: temperature-sensitive units in lizard brain. Science 158, 1050-1051.

Cabanac, M., Laberge, F., 1998. Fever in goldfish is induced by pyrogens but not by handling. Physiol. Behav. 63, 377-379.

Campbell, J., Kessler, B., Mayack, C., Naug, D., 2010. Behavioural fever in infected honeybees: parasitic manipulation or coincidental benefit? Parasitology 137, 1487-1491.

Carey, F.G., Teal, J.M., 1966. Heat conservation in tuna fish muscle. Proc. Natl. Acad. Sci. U. S. A. 56, 1464-1469.

Casterlin, M.E., Reynolds, W.W., 1977. Behavioral fever in anuran amphibian larvae. Life Sci. 20, 593-596.

Chai, Z., Gatti, S., Toniatti, C., Poli, V., Bartfai, T., 1996. Interleukin (IL)-6 gene expression in the central nervous system is necessary for fever response to lipopolysaccharide or IL-1 beta: a study on IL-6-deficient mice. J. Exp. Med. 183, $311-316$.

Covert, J.B., Reynolds, W.W., 1977. Survival value of fever in fish. Nature 267, 43-45. 
Crack, P.J., Bray, P.J., 2007. Toll-like receptors in the brain and their potential roles in neuropathology. Immunol. Cell Biol. 85, 476-480.

Craig, A.D., 2002. How do you feel? Interoception: the sense of the physiological condition of the body. Nat. Rev. Neurosci. 3, 655-666.

Dickson, K.A., Graham, J.B., 2004. Evolution and consequences of endothermy in fishes. Physiol. Biochem. Zool. 77, 998-1018.

Dinarello, C.A., 1999. Cytokines as endogenous pyrogens. J. Infect. Dis. 179, 294-304.

Dinarello, C.A., Cannon, J.G., Wolff, S.M., Bernheim, H.A., Beutler, B., Cerami, A., Figari, I.S., Palladino Jr., M.A., O'Connor, J.V., 1986. Tumor necrosis factor (cachectin) is an endogenous pyrogen and induces production of interleukin 1. J. Exp. Med. 163, 1433-1450.

do Amaral, J.P., Marvin, G.A., Hutchison, V.H., 2002. The influence of bacterial lipopolysaccharide on the thermoregulation of the box turtle Terrapene carolina. Physiol. Biochem. Zool. 75, 273-282.

Don, M., Estany, A., Ramos, A., Leoni, R., Muchlinski, A., 1994. Re-examination of the afebrile response in two lizard species (Varanus exanthematicus and Gerrhosaurus major). J. Herpetol. 28, 385-388.

Elliot, S.L., Blanford, S., Thomas, M.B., 2002. Host-pathogen interactions in a varying environment: temperature, behavioural fever and fitness. Proc. R. Soc. B Biol. Sci. 269, 1599-1607.

Engblom, D., Saha, S., Engstrom, L., Westman, M., Audoly, L.P., Jakobsson, P.-J., Blomqvist, A., 2003. Microsomal prostaglandin E synthase-1 is the central switch during immune-induced pyresis. Nat. Neurosci. 6, 1137-1138.

Engstrom, L., Ruud, J., Eskilsson, A., Larsson, A., Mackerlova, L., Kugelberg, U., Qian, H., Vasilache, A.M., Larsson, P., Engblom, D., Sigvardsson, M., Jonsson, J.I., Blomqvist, A., 2012. Lipopolysaccharide-induced fever depends on prostaglandin E2 production specifically in brain endothelial cells. Endocrinology 153, 4849-4861.

Evans, S.S., Repasky, E.A., Fisher, D.T., 2015. Fever and the thermal regulation of immunity: the immune system feels the heat. Nat. Rev. Immunol. 6, 335-349.

Goldman, J.K., 1997. Regulation of body temperature in the white shark, Carcharodon carcharias. J. Comp. Physiol. B 167, 423-429.

Grans, A., Rosengren, M., Niklasson, L., Axelsson, M., 2012. Behavioural fever boosts the inflammatory response in rainbow trout Oncorhynchus mykiss. J. Fish. Biol. 81, 1111-1117.

Hallman, G.M., Ortega, C.E., Towner, M.C., Muchlinski, A.E., 1990. Effect of bacterial pyrogen on three lizard species. Comp. Biochem. Physiol. A Physiol. 96, 383-386.

Hamzic, N., Tang, Y., Eskilsson, A., Kugelberg, U., Ruud, J., Jonsson, J.I., Blomqvist, A., Nilsberth, C., 2013. Interleukin-6 primarily produced by non-hematopoietic cells mediates the lipopolysaccharide-induced febrile response. Brain. Behav. Immun. 33, 123-130.

Harlow, P., Grigg, G., 1984. Shivering thermogenesis in a brooding diamond python, Python spilotes spilotes. Copeia 1984, 959-965.

Hutchison, V.H., Dowling, H.G., Vinegar, A., 1966. Thermoregulation in a brooding female Indian python, Python molurus bivittatus. Science 151, 694-696.

Hutchison, V.H., Erskine, D.J., 1981. Thermal selection and prostaglandin E1 fever in the salamander Necturus maculosus. Herpetologica 37, 195-198.

Ikejima, T., Okusawa, S., Ghezzi, P., van der Meer, J.W., Dinarello, C.A., 1990. Interleukin-1 induces tumor necrosis factor (TNF) in human peripheral blood mononuclear cells in vitro and a circulating TNF-like activity in rabbits. J. Infect. Dis. 162, 215-223.

IUPS, 2001. Glossary of terms for thermal physiology. Jpn. J. Physiol. 245-280.

Ivanov, A.I., Romanovsky, A.A., 2004. Prostaglandin E2 as a mediator of fever: synthesis and catabolism. Front. Biosci. 9, 1977-1993.

Kluger, M.J., 1977. Fever in the frog Hyla Cinerea. J. Therm. Biol. 2, 79-81.

Kluger, M.J., 1979. Phylogeny of fever. Fed. Proc. 38, 30-34.

Kluger, M.J., Kozak, W., Conn, C.A., Leon, L.R., Soszynski, D., 1998. Role of fever in disease. Ann. N. Y. Acad. Sci. 856, 224-233.

Kluger, M.J., Ringler, D.H., Anver, M.R., 1975. Fever and survival. Science 188, $166-168$.

Kozak, W., Kluger, M.J., Soszynski, D., Conn, C.A., Rudolph, K., Leon, L.R., Zheng, H., 1998. IL-6 and IL-1 beta in fever. Studies using cytokine-deficient (knockout) mice. Ann. N. Y. Acad. Sci. 856, 33-47.

Kwiatkowski, D., 1989. Febrile temperatures can synchronize the growth of Plasmodium falciparum in vitro. J. Exp. Med. 169, 357-361.

Laburn, H.P., Mitchell, D., Kenedi, E., Louw, G.N., 1981. Pyrogens fail to produce fever in a cordylid lizard. Am. J. Physiol. 241, R198-R202.

Laflamme, N., Rivest, S., 1999. Effects of systemic immunogenic insults and circulating proinflammatory cytokines on the transcription of the inhibitory factor kappaB alpha within specific cellular populations of the rat brain. J. Neurochem. 73, 309-321.

Launey, Y., Nesseler, N., Mallédant, Y., Seguin, P., 2011. Clinical review: fever in septic ICU patients - friend or foe? Crit. Care 15, 222.

Lazarus, M., Yoshida, K., Coppari, R., Bass, C.E., Mochizuki, T., Lowell, B.B., Saper, C.B., 2007. EP3 prostaglandin receptors in the median preoptic nucleus are critical for fever responses. Nat. Neurosci. 10, 1131-1133.

Li, Z., Perlik, V., Feleder, C., Tang, Y., Blatteis, C.M., 2006. Kupffer cell-generated PGE 2 triggers the febrile response of guinea pigs to intravenously injected LPS. Am. J. Physiol. Regul. Integr. Comp. Physiol. 290, R1262-R1270.

Mackowiak, P.A., Marling-Cason, M., Cohen, R.L., 1982. Effects of temperature on antimicrobial susceptibility of bacteria. J. Infect. Dis. 145, 550-553.

Martel, A., Blooi, M., Adriaensen, C., Van Rooij, P., Beukema, W., Fisher, M.C., Farrer, R.A., Schmidt, B.R., Tobler, U., Goka, K., Lips, K.R., Muletz, C., Zamudio, K.R., Bosch, J., Lotters, S., Wombwell, E., Garner, T.W.,
Cunningham, A.A., Spitzen-van der Sluijs, A., Salvidio, S., Ducatelle, R., Nishikawa, K., Nguyen, T.T., Kolby, J.E., Van Bocxlaer, I., Bossuyt, F., Pasmans, F., 2014. Wildlife disease. Recent introduction of a chytrid fungus endangers Western Palearctic salamanders. Science 346, 630-631.

Marx, J., Hilbig, R., Rahmann, H., 1984. Endotoxin and prostaglandin E1 fail to induce fever in a teleost fish. Comp. Biochem. Physiol. A Physiol. 77, 483-487.

Matsumura, K., Cao, C., Ozaki, M., Morii, H., Nakadate, K., Watanabe, Y., 1998. Brain endothelial cells express cyclooxygenase-2 during lipopolysaccharide-induced fever: light and electron microscopic immunocytochemical studies. J. Neurosci. 18, 6279-6289.

McKinley, M.J., McAllen, R.M., Davern, P., Giles, M.E., Penschow, J., Sunn, N., Uschakov, A., Oldfield, B.J., 2003. The sensory circumventricular organs of the mammalian brain. Adv. Anat. Embryol. Cell Biol. 172, 1-122.

Merchant, M., Fleury, L., Rutherford, R., Paulissen, M., 2008. Effects of bacterial lipopolysaccharide on thermoregulation in green anole lizards (Anolis carolinensis). Vet. Immunol. Immunopathol. 125, 176-181.

Merchant, M., Williams, S., Trosclair 3rd, P.L., Elsey, R.M., Mills, K., 2007. Febrile response to infection in the American alligator (Alligator mississippiensis). Comp. Biochem. Physiol. A Mol. Integr. Physiol. 148, 921-925.

Milton, A.S., Wendlandt, S., 1971. Effects on body temperature of prostaglandins of the $\mathrm{A}, \mathrm{E}$ and $\mathrm{F}$ series on injection into the third ventricle of unanaesthetized cats and rabbits. J. Physiol. 218, 325-336.

Mogensen, T.H., 2009. Pathogen recognition and inflammatory signaling in innate immune defenses. Clin. Microbiol. Rev. 22, 240-273.

Mohammed, R.S., Reynolds, M., James, J., Williams, C., Mohammed, A., Ramsubhag, A., van Oosterhout, C., Cable, J., 2016. Getting into hot water: sick guppies frequent warmer thermal conditions. Oecologia 181, 911-917.

Monagas, W.R., Gatten Jr., R.E., 1983. Behavioural fever in the turtles Terrapene carolina and Chrysemys picta. J. Therm. Biol. 8, 285-288.

Muchlinski, A.E., Estany, A., Don, M.T., 1995. The response of Anolis equestris and Oplurus cyclurus (Reptilia: Iguanidae) to bacterial endotoxin. J. Therm. Biol. 20, 315-320.

Murphy, P.J., St-Hilaire, S., Corn, P.S., 2011. Temperature, hydric environment, and prior pathogen exposure alter the experimental severity of chytridiomycosis in boreal toads. Dis. Aquat. Organ 95, 31-42.

Myhre, K., Cabanac, M., Myhre, G., 1977. Fever and behavioural temperature regulation in the frog Rana esculenta. Acta Physiol. Scand. 101, 219-229.

Nadjar, A., Tridon, V., May, M.J., Ghosh, S., Dantzer, R., Amedee, T., Parnet, P., 2005. NFkappaB activates in vivo the synthesis of inducible Cox-2 in the brain. J. Cereb. Blood Flow. Metab. 25, 1047-1059.

Nakamura, K., 2011. Central circuitries for body temperature regulation and fever Am. J. Physiol. Regul. Integr. Comp. Physiol. 301, R1207-R1228.

Nakamura, K., Matsumura, K., Kaneko, T., Kobayashi, S., Katoh, H., Negishi, M., 2002 The rostral raphe pallidus nucleus mediates pyrogenic transmission from the preoptic area. J. Neurosci. 22, 4600-4610.

Navarro, V.P., Iyomasa, M.M., Leite-Panissi, C.R., Almeida, M.C., Branco, L.G., 2006. New role of the trigeminal nerve as a neuronal pathway signaling brain in acute periodontitis: participation of local prostaglandins. Pflugers Arch. 453, 73-82.

Nelson, D.O., Prosser, C.L., 1979. Effect of preoptic lesions on behavioral thermoregulation of green sunfish, Lepomis cyanellus, and of goldfish, Carassius auratus J. Comp. Physiol. 129, 193-197.

Netea, M.G., Kullberg, B.J., Van der Meer, J.W.M., 2000. Circulating cytokines as mediators of fever. Clin. Infect. Dis. 31, 178-184.

Novoa, B., Mackenzie, S., Figueras, A., 2010. Inflammation and innate immune response against viral infections in marine fish. Curr. Pharm. Des. 16, 4175-4184.

O'Neill, L.A.J., Golenbock, D., Bowie, A.G., 2013. The history of Toll-like receptorsredefining innate immunity. Nat. Rev. Immunol. 13, 453-460.

Oka, T., 2004. Prostaglandin E2 as a mediator of fever: the role of prostaglandin E (EP) receptors. Front. Biosci. 9, 3046-3057.

Ortega, C.E., Stranc, D.S., Casal, M.P., Hallman, G.M., Muchlinski, A.E., 1991. A positive fever response in Agama agama and Sceloporus orcutti (Reptilia: agamidae and Iguanidae). J. Comp. Physiol. B Biochem. Syst. Environ. Physiol. 161, 377-381.

Pecchi, E., Dallaporta, M., Jean, A., Thirion, S., Troadec, J.D., 2009. Prostaglandins and sickness behavior: old story, new insights. Physiol. Behav. 97, 279-292.

Prosser, C.L., Nelson, D.O., 1981. The role of nervous systems in temperature adaptation of poikilotherms. Annu. Rev. Physiol. 43, 281-300.

Ramos, A.B., Don, M.T., Muchlinski, A.E., 1993. The effect of bacteria infection on mean selected body temperature in the common Agama, Agama agama: a doseresponse study. Comp. Biochem. Physiol. Comp. Physiol. 105, 479-484.

Reid, A.Y., Galic, M.A., Teskey, G.C., Pittman, Q.J., 2009. Febrile seizures: current views and investigations. Can. J. Neurol. Sci. 36, 679-686.

Rey, S., Huntingford, F.A., Boltaña, S., Vargas, R., Knowles, T.G., Mackenzie, S., 2015. Fish can show emotional fever: stress-induced hyperthermia in zebrafish. Proc. R. Soc. B Biol. Sci. 282.

Reynolds, W.W., 1977. Fever and antipyresis in the bluegill sunfish, Lepomis macrochirus. Comp. Biochem. Physiol. C. Comp. Pharmacol. 57, 165-167.

Reynolds, W.W., Casterlin, M.E., 1982. The pyrogenic responses of non-mammalian vertebrates. In: Milton, A. (Ed.), Pyretics and Antipyretics. Springer Berlin Heidelberg, pp. 649-668.

Reynolds, W.W., Casterlin, M.E., Covert, J.B., 1976. Behavioural fever in teleost fishes. Nature 259, 41-42.

Reynolds, W.W., Covert, J.B., Casterlin, M.E., 1978. Febrile responses of goldfish Carassius auratus (L.) to Aeromonas hydrophila and to Escherichia coli endotoxin. J. Fish. Dis. 1, 271-273. 
Richards-Zawacki, C.L., 2010. Thermoregulatory behaviour affects prevalence of chytrid fungal infection in a wild population of Panamanian golden frogs. Proc. R. Soc. Lond. B. Biol. Sci. 277, 519-528.

Rivest, S., 2003. Molecular insights on the cerebral innate immune system. Brain. Behav. Immun. 17, 13-19.

Romanovsky, A.A., 2000. Thermoregulatory manifestations of systemic inflammation: lessons from vagotomy. Auton. Neurosci. 85, 39-48.

Roth, J., Blatteis, C.M., 2014. Mechanisms of fever production and lysis: lessons from experimental LPS fever. Compr. Physiol. 4, 1563-1604.

Roth, J., de Souza, G.E.P., 2001. Fever induction pathways: evidence from responses to systemic or local cytokine formation. Braz. J. Med. Biol. Res. 34, 301-314.

Roth, J., Harre, E.M., Rummel, C., Gerstberger, R., Hubschle, T., 2004. Signaling the brain in systemic inflammation: role of sensory circumventricular organs. Front. Biosci. 9, 290-300.

Rummel, C., Sachot, C., Poole, S., Luheshi, G.N., 2006. Circulating interleukin-6 induces fever through a STAT3-linked activation of COX-2 in the brain. Am. J. Physiol. Regul. Integr. Comp. Physiol. 291, R1316-R1326.

Rummel, C., Voss, T., Matsumura, K., Korte, S., Gerstberger, R., Roth, J., Hubschle, T., 2005. Nuclear STAT3 translocation in guinea pig and rat brain endothelium during systemic challenge with lipopolysaccharide and interleukin-6. J. Comp. Neurol. 491, 1-14.

Saper, C.B., Romanovsky, A.A., Scammell, T.E., 2012. Neural circuitry engaged by prostaglandins during the sickness syndrome. Nat. Neurosci. 15, 1088-1095.

Satinoff, E., McEwen Jr., G.N., Williams, B.A., 1976. Behavioral fever in newborn rabbits. Science 193, 1139-1140.

Schall, J.J., 1990. Virulence of lizard malaria: the evolutionary ecology of an ancient parasite-host association. Parasitology 100, S35-S52.

Schindler, R., Mancilla, J., Endres, S., Ghorbani, R., Clark, S.C., Dinarello, C.A., 1990 Correlations and interactions in the production of interleukin-6 (IL-6), IL-1, and tumor necrosis factor (TNF) in human blood mononuclear cells: IL-6 suppresses IL-1 and TNF. Blood 75, 40-47.

Sherman, E., Baldwin, L., Fernandez, G., Deurell, E., 1991. Fever and thermal tolerance in the toad Bufo marinus. J. Therm. Biol. 16, 297-301.

Simm, B., Ott, D., Pollatzek, E., Murgott, J., Gerstberger, R., Rummel, C., Roth, J., 2016. Effects of prostaglandin E2 on cells cultured from the rat organum vasculosum laminae terminalis and median preoptic nucleus. Neuroscience 313, 23-35.

Soares, D.M., Figueiredo, M.J., Martins, J.M., Machado, R.R., Kanashiro, A. Malvar, D.d.C., Pessini, A.C., Roth, J., Souza, G.E.P., 2009. CCL3/MIP- $1 \alpha$ is not involved in the LPS-induced fever and its pyrogenic activity depends on CRF. Brain Res. 1269, 54-60.
Steiner, A.A., Ivanov, A.I., Serrats, J., Hosokawa, H., Phayre, A.N., Robbins, J.R., Roberts, J.L., Kobayashi, S., Matsumura, K., Sawchenko, P.E., Romanovsky, A.A. 2006. Cellular and molecular bases of the initiation of fever. PLoS Biol. 4, e284.

Steiner, A.A., Rudaya, A.Y., Robbins, J.R., Dragic, A.S., Langenbach, R., Romanovsky, A.A., 2005. Expanding the febrigenic role of cyclooxygenase-2 to the previously overlooked responses. Am. J. Physiol. Regul. Integr. Comp. Physiol. 289, R1253-R1257.

Stevens, E.D., Fry, F.E.J., 1971. Brain and muscle temperatures in ocean caught and captive skipjack tuna. Comp. Biochem. Physiol. Part A Physiol. 38, 203-211.

Tattersall, G.J., 2016. Reptile thermogenesis and the origins of endothermy. Zool. (Jena). http://dx.doi.org/10.1016/j.zool.2016.03.001.

Tattersall, G.J., Leite, C.A., Sanders, C.E., 2016. Seasonal reproductive endothermy in tegu lizards. Sci. Adv. 2, e1500915.

Tavares, E., Miñano, F.J., Maldonado, R., Dascombe, M.J., 2006. Endotoxin fever in granulocytopenic rats: evidence that brain cyclooxygenase-2 is more important than circulating prostaglandin E2. J. Leukoc. Biol. 80, 1375-1387.

Ushikubi, F., Segi, E., Sugimoto, Y., Murata, T., Matsuoka, T., Kobayashi, T., Hizaki, H., Tuboi, K., Katsuyama, M., Ichikawa, A., Tanaka, T., Yoshida, N., Narumiya, S., 1998. Impaired febrile response in mice lacking the prostaglandin E receptor subtype EP3. Nature 395, 281-284.

Vaughn, L.K., Bernheim, H.A., Kluger, M.J., 1974. Fever in the lizard Dipsosaurus dorsalis. Nature 252, 473-474.

Wegner, N.C., Snodgrass, O.E., Dewar, H., Hyde, J.R., 2015. Whole-body endothermy in a mesopelagic fish, the opah, Lampris guttatus. Science 348, 786-789.

Yamagata, K., Matsumura, K., Inoue, W., Shiraki, T., Suzuki, K., Yasuda, S., Sugiura, H., Cao, C., Watanabe, Y., Kobayashi, S., 2001. Coexpression of microsomal-type prostaglandin E synthase with cyclooxygenase-2 in brain endothelial cells of rats during endotoxin-induced fever. J. Neurosci. 21, 2669-2677.

Zetterstrom, M., Sundgren-Andersson, A.K., Ostlund, P., Bartfai, T., 1998. Delineation of the proinflammatory cytokine cascade in fever induction. Ann. N. Y. Acad. Sci. $856,48-52$.

Zou, J., Neumann, N.F., Holland, J.W., Belosevic, M., Cunningham, C., Secombes, C.J., Rowley, A.F., 1999. Fish macrophages express a cyclo-oxygenase-2 homologue after activation. Biochem. J. 340, 153-159.

Zurovsky, Y., Brain, T., Laburn, H., Mitchell, D., 1987a. Pyrogens fail to produce fever in the snakes Psammophis phillipsii and Lamprophis fuliginosus. Comp. Biochem. Physiol. A Physiol. 87, 911-914.

Zurovsky, Y., Mitchell, D., Laburn, H., 1987b. Pyrogens fail to produce fever in the leopard tortoise Geochelone pardalis. Comp. Biochem. Physiol. A Comp. Physiol. 87, 467-469. 